\title{
バタヴィアの都市形態と S.ステヴィンの「理想都市」計画に関する比較考察 COMPARATIVE CONSIDERATIONS ON THE URBAN FORM OF BATAVIA AND SIMON STEVIN'S 'IDEAL CITY' PLAN
}

\author{
布野修司*, 山田協太**, 山本直彦*** \\ Shuji FUNO, Kyota YAMADA and Naohiko YAMAMOTO
}

\begin{abstract}
Authors have been conducting the field research under the title ' Origin, Transformation, Alteration and Conservation of Urban Space of Colonial cities' since 1999. The cities where we carried out field studies are Cape Town(South Africa), Cochin(India), Galle(Sri Lanka), Malacca(Malaysia), Jakarata, Surabaya(Indonesia), Elmina(Ghana), Recife(Brazil), Paramaribo(Suriname), Willemstad(Dutch Antilles) etc.. We had grasped almost all the factories, forts and cities constructed by VOC and WIC, collecting old maps, documents and literatures from ARA(Algemeen Rijksarchief), KB(Koninklijke Bibliotheek) in Den Haag and KITLV(Koninklijk Institut voor Taal-, Land- en Volkenkunde) in Leiden.

Batavia was the capital of VOC which was called 'Queen of Asia'. The plan of Batavia is thought to follow the plans of cities in mother country as Amsterdam, Delft and so on. Among many architects and engineers who were active in $16^{\text {th }}$ century, Simon Stevin attracts us as a theorist of urban planning. This paper discusses the relationship between the spatial form of Batavia and S. Stevin's 'Ideal City'.
\end{abstract}

Keywords : Batavia, Simon Stevin, Dutch Colonial City, Ideal City バタヴィア、S.ステヴィン、オランダ植民都市、理想都市

\section{1 研究の目的之背景}

本稿は、「植民都市空間の起原・変容・転成・保全に関する調查研究」と 題する研究の一環として、オランダ東インド会社の拋点都市、そしてオラン ダ領東インドの首都として建設されたバタヴィアを対象として、その建設過 程を検討し、その計画理念について考察することを目的としている。

俗に、バタヴィアはアムステルダムを模して計画されたという。しかし、 半円形をしたアムステルダムの現在の形態とは異なっている。形態として似 ているのは、むしろデルフトである。ところが、バタヴィアが建設されつつ あった 16 世紀半ば䪸までのアムステルダムを見ると、アムステル川を中央 に置いた運河のシステムはバタヴィアに似ている。少なくとも、運河を設け てポルダーpolder (宅地) をつくってでくシステムには共通性があるように 思われる。本国における都市計画技術稙民地においても用いられたことは いうまでもないことである。

本稿では、バタヴィアの都市計画をオランタにおける都市計画理念、とり わけ、S. ステヴィンの「理想都市」計画案と比較考察したい。S.ステヴィ ンはその「理想都市」計画案にオランダの都市計画手法の粋を集約していた と考えられている。

一見バタヴィアとS．ステヴィンのモデルは必ずしも似てはいない。S． ステヴィンの案がバタヴィアに送られたという事実を実証した R.ラベンはは S. ステヴィンの「理想都市」計画案とは似ても似つかないといゔ。果たし てそうか。いくつかの視点を設定して、バタヴィアとS.ステヴィンの「理想 都市」計画モデルとの異同を以下に明らかにする。

\section{2 バタヴィアの建設と空間搆成}

バタヴィアの歴史については、F. de ハーンによる 3 卷からなる古典的名 著『古バ夕ヴィア』奴ある。また、初期バ夕ヴィアの多民族的構成とその変 容を扱う P.D.ミローンMilone 5、植民都市を比較するJ.L.コバーン Cobban 6、奴隷制に焦点を当てるS.アベヤセケレ Abeyasekere ?、ユーレイシアン世 界に焦点を当てる J.G.テイラーTaylor ${ }^{8}$ なと数多くの論考がある。その膨大 な文献のリストは、2000 年に E.エビングと Y.デ・ヤガーによって、ライデ ン大学の王立民族文化研究所 KITLV から出版されている9。 た、バタヴィアに関するオランダ 東インド会社 (VOC) 関連の歴 史地図については、B.ブロマーと D.デ・フリース10が網羅するとこ ろである。歷史地図はA〜Fのグ ループに分けられる。A. バタヴ イア包囲 1629 (BAT h01 K10)、 B. 大地図 1650 (BAT K11 K28)、C. バタヴィアとその周辺 (BAT K29 K36)、D. バタヴィ ア 1680 年頃 (BAT K37 から K40)、E. 1731 年地図 (BAT K41

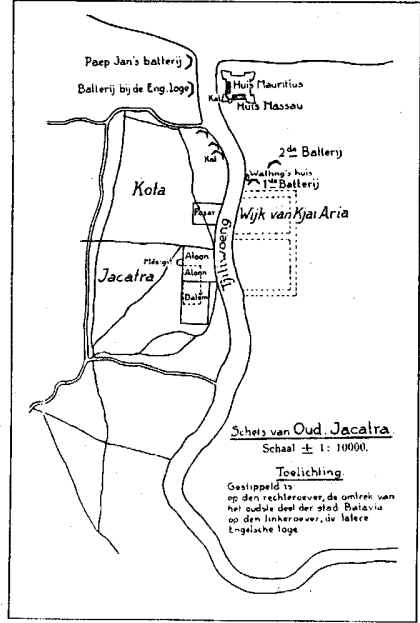

図1 ジャカトラ復元図 J.W.エイゼレマン 1917 年
* 滋賀県立大学大学院環境科学研究科 教授 - 工博

** 京都大学大学院工学研究科 博士後期課程. 工修

*** 滋賀県立大学大学院瑙境科学研究科 講師・工博
Prof., The University of Shiga Pref., Dr. Eng. Graduate Student, Kyoto University, M. Eng. Lecturer, The University of Shiga Pref., Dr. Eng. 
〜K46)、F. バタヴィア 1764 年頃（BAT K47〜49)、G.その他 (BAT50,51) である。その他に手書きの地図が 31 (BAT M01〜M19）（BAT MP01〜 MP12)、さらに絵画、スケッチなどで栕されたものが38 (A〜E:BAT P01 〜P38)、ある。本稿では、バタヴィアの建設過程について詳述する余裕はな いが、考察に必要な範用で、以上の古図に依りながら、バタヴィアの都市形 成過程と空間構成をまとめると以下のようになる。

(1スンタ・カラパ/ジャヤカルタ・ジャカトラ

バタヴィア/ジャカルタの地は、もともとスンダ・カラパSunda Kalapa と呼ばれていた。スンダは地域名、カラパは楖子という意味である。1527 年にイスラーム聖人スナン・グヌン・ジャティがスンダ・カラパを征服し、 ジャヤカルタ Jayakarta と改名11され、バントゥン王国の支配下に入った。
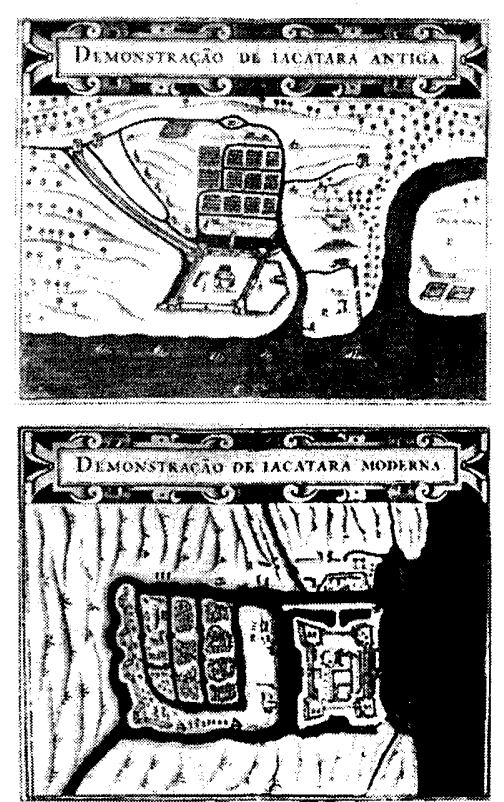

図2 ジャカトラ Pedro Ber thelot8ATMO3

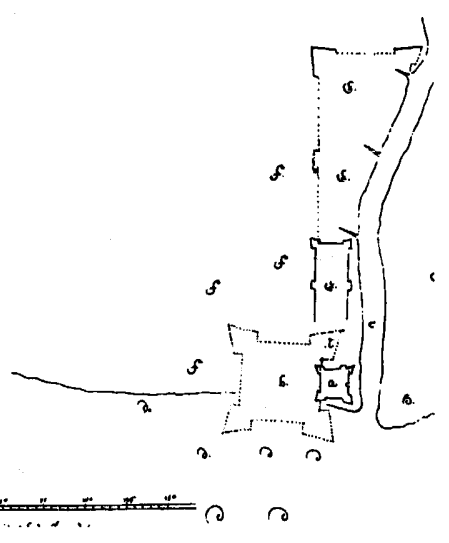

图3 クーンのスケッチ BAT M01

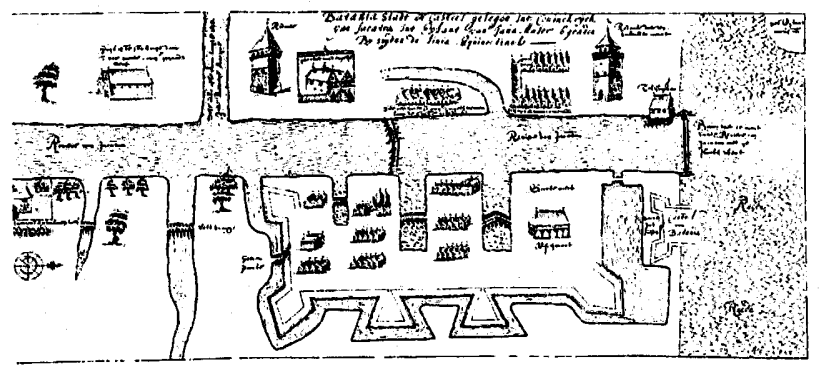

图4 ハイタウィア 1622〜23年 BAT MO2
の状况がわかる 2 葉の地図 DEMONSTRACAO DE IACATARA ANTIGA （図 2 BAT M03）16である。前者は、要塞は簡易であり、運河も整理されて いない。何よりも興味深いのは、要塞外にカンポン (オランダ人によってク ワルティール kwartier（地区 quarter）と呼ばれるようになる）の形式が模 式的に書かれていることである。商館、要塞化した商館、要塞、要塞十都市 集落 (城塞) という植民都市の建設過程がモデルとして示されている。

\section{(3)゙タヴィア城の建設}

1618 年に VOC 評議会は植民拠点の建設を決意する。そして、1618 年 4 月 に 5 角形の要塞案と $S$. ステヴィンの 4 角形の要塞および都市案を送っている 17。1619 年に要塞建設が開始されたが、クーンが採用したのは 4 角形案であ った。1920 年の末には 2 つ稜堡か浣成している。新しい要塞と都市がオラ ンダの古名に因みバタヴィアと名づけられたのは 1621 年8月 21 日である18。

最も古い地図は、クーンが 17 人重役会」に送つたごく簡単なスケッチ（図 3 BAT M01 1619) である。1618 年に建てられたジャカトラ要塞の東にS. ステヴィンが設計したとされるバ夕ヴィア城が波線て描かれている。残存す る第 2 の地図は 1622〜23 年頃のもの（図4 BAT M02）で、素人っぽいが バタヴィアをよく知ったものが書いたと思われ、櫛の様な土地に橋が渡され、 建物が連棟式に描れている。ペドロ・ベルトレットの図の前期（上）のも の (BATM03 図2) に対応していると考えられる。

バ夕ヴィア城 Kasteel Batavia の敷地は約 $3.6 \mathrm{ha}(200 \mathrm{~m} \times 180 \mathrm{~m})$ で、4つの 稜堡はダイヤモンド Diamant、ルビーRobijn、パール Parel、サファイア Saffier と呼ばれたが、水造杭の上に珊瑚を積んでつくられ約20ft高さがあった。 また、周囲は海水を満たした嫁で冊われた。完成したのは 1650 年頃である。 バタヴィア城は、17 世紀にヨーロッバ諸国が東洋に建てた要塞のうち最大で 様々な要素を含んだ複合建築である。多くの前哨や要塞の中心であり、総督 か蓻務室を持ち、裁判所、教会、商館、嬠楽施設 Speelhuisje を持っていた19。 (4)バタウィアの抬張（1627-35）

チリウン川東岸に着々と市街を建設したオランダに対して、1627 年に、 バントゥン王国とマタラム王国の連合軍か攻撃を仕掛けるが、この攻撃を退 けて、バタヴィア城は確固とした都市へと発展を遂げることになる。建設過 程についてはおよそ明らかにされているが。、その任を担ったのは、クーン の後を引き継いだ第 6 代総督ヤックス・スペックス Jacques Specx（在任 1629-32）である21。スペックスが着任した段階でチリウン川東岸が㸞地と なっていたのであるが、その状況をしめすのが、Aバタヴィア包囲の図群で ある。中でもギルズ・フェナント2によよて描かれた地図 (図 5 BAT M06 1629）か精朽である。また、ファン・ベルケンローデのバタヴィア包囲の図 (BATM05 1628-9) がある。

スペックスがまず行ったのは東の市壁 Stadsoostwal の再建である。1627 年頃東側につくられた市壁は当初木妌を用いた簡素なもので、斜めに走って いたけれど、南北直線の形に直された。また、1632 年までに、幅 300ft、水 深 100ft のオースタースタッツブイテン（東市区）運河がオースタースタッ ツ全体を取り囲むように掘削された。最初の運河は市壁と同様東南向きに斜 めに掘られていたが、市壁に合わせて直線に直された。当初はタヨリン運河 Tayolinsgracht と呼ばれ、同じようにフィアデドワルス運河 Vierdedwarsgracht からチリウン川まで斜めに走っていたオースタースタッツビネン運河 Oosterstadsbinnengracht もオースタースタッツブイテン運河に平行に市内側に 掘られている。

そして、蛇行していたチリウン川を直線とし(グローテ・リヴィール Groote Rivier 大川)、西岸のジャやカル夕王国の立地した市街用地を囲む運河を掘 っている。スペックスの時代に、市域は東オースタースタット Oosterstad、 
西ウェスタースタット Westerstad、市壁外南の前フォアスタット Voorstad の3つに区分された。その建設は第7代ヘンドリック・ボウワーHendrik Bouwer(1632-36)に引き継が㧈る。

\section{(5バタビア城塞の完成}

ヘンドリック・ボウアーを引き継いだのはアントニオ・ファン・ディーメ

ン Antonio van Diemen(1636-45) とコルネリス・ファン・デル・レイン Cornelis van der Lijn(1645-1650)である。彼らはスペックスの事業を弓継ぎ、 市壁、稜堡は煉瓦造に造り替え、市街建設も進める。東地区に病院、西地区 には監獄が建設された。また、運河もムーア運河 Moorsegracht、ヨンカー 運河 Jonkersgrachtなど続けて掘削されている。チリウン川に平行してワン ブロック西のヨンカー運河 Jonkersgracht は 1637 年から 1638 年にかけて建設 され,マレー運河 Maleisegracht とウェスタースタッツビネン運河の南を繋い でいる。1636 年からライノセロ運河 Rhinocerosgracht がヨンカ一運河に平行 してマレ一運河からウェスタースタッツビネン運河 まで掘削された。西側 にある形務所 Spinhuis に因んでスピンハイス運河 Spinhuisgracht と呼ばれる。 後にはジャワ運河まで延長される。延長部分がムーア運河である。インド人 ムスリムが多く住んだからである。

また、2つの市門、北にワーテルポート (水門)、南にニーウポールト (新 門) が設置された。1650 年代には最終形態をとることになる。市域はバ夕 ヴィア城を合わせて、140ヘクタールとなる。

人口密度が高まるにつれて、火災の危険が意識され、1654 年には東地区 の建造物性䐈瓦造あるいは石造とすることが推将される。東インド会社の職 人、バンダ人住区のみは竹の建築のままであったが、1657 年には東地区の 全ての建造物は石造となった23。1669年には、城塞内は建て詰まったと言わ れる。郊外については、東はかなり整然と計画されたが、西側はかなり不規 則に発展したかたちとなった。

バタヴィア城塞の骨格ができあがった段階の状况を示すのが 1650 年頃の 大地図B群（BAT K11〜K28）である。元になるのは、1650年のデ・ヨン グ Clement de Jonghe の地図（図6 BAT K11）、1652 年のヤンソニウス Janssonius の地図(BAT K13)、1653 年のデ・ウィットDe Wit の地図(BAT K14)、1669 年のモンタヌス Montanus の地図（BAT K15）である。合わ せて9つのヴァージョンがある。また、手書きのものとして、1650 年のパ ウルス Paulus の地図がある。

\section{S.ステヴィンと「理想都市」}

\section{3-1 S.ステヴィンの著作}

ステヴィンが 1548 年にブリュージュで生まれたことは伝えられるが、 33 才でライデンに現れるまではあまりはっきりしない。アントワープの商家で 事務員として働き、その後ヘントの行政組織にいたことが知られる。1581 年 にライデンに現れていくつかの著作誗子の表』(1582 年)『十進法について』 （1585 年）『重さの学の諸原理』（1586 年）『水の重さの諸原理』（1586 年） を著す。K.ファン・ベルケルレ゙によれば、1593 年頃、マウリッツに私的に仕 える技術者となり、1604 年に連邦陸軍の補給将校に任命される。マウリッツ は応用数学に興味をもったというが、個人教授の内容をまとめたのが『数学 的考察』(1605-08 年) だしいう。そして、数学や物理、自然科学に関する著 作の他、築城術や都市計画に関する著作がある。要塞建設 Stercktenbouwing 』 (1594 年)、『要塞術 Castrametatio』（1617 年）などである。死後、息子のヘン ドリック Hendrickがまとめた著作集『民生問題 Materiae Politicae. Burgherlicke Stoffen (Civic Matters)』(1649 年)には「都市住居計画 Vande Oirdening der Steden and Vande Oirdening der deelen eens huys met 't gheene daer ancleeft」がある。ステ

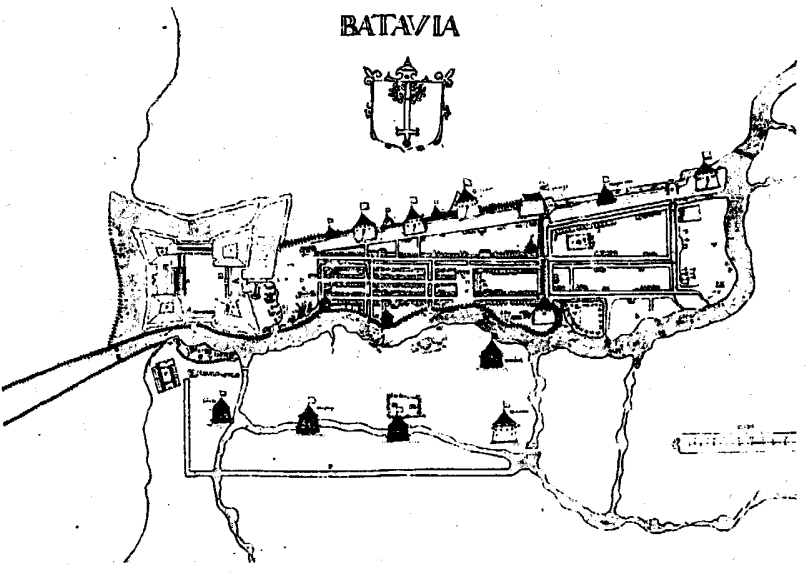

图5 バタヴア1629年 BAT Mo6

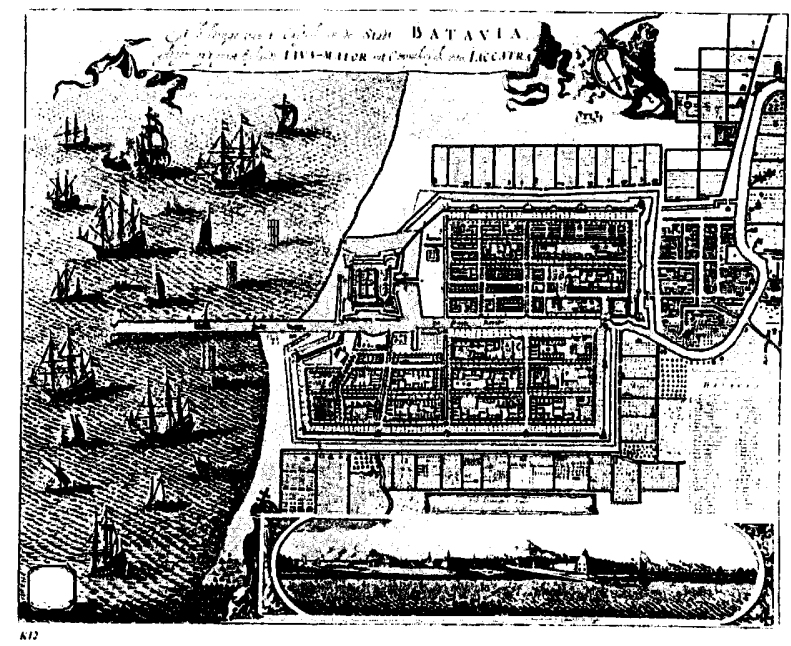

图6 バタウィア 1650 年 Bat K11

ヴィンは『住宅建築 Huysbou (House Building)』を出版する予定であったが陽 の目はみなかった。港発見法』(1599 年) のような著作もある。

EJ.ダイクステルフイス Dijksterhuis 編の、全 5 巻からなる『S.ステヴィン の主要著作』 ${ }^{25}$ にって、その全貌を窥うことができる。第 I 巻にステヴィ ンの仕事と著作リストがまとめられている。

彼は発明のための特許の審査に関わる委員会のメンバーであり、ライデン 大学の技術学校「ネーデルダッチ・マテマティーク (オランダ数学)」 Nederduytsche Mathematique の設立（1600年）にも関わっている。『十進法に ついて』は、「天体観察者、土地測量者、䋐逖計測者、ワイン検量者、身体 計測者、貨幣鋳造者、そして全ての商人」に献げられている。ステヴィンは、 オランタ語で、日常語で一般にわかりやすく書くことを基本にしていた。共 和国成立当時、ネーデルランドにはネーデルランド独自の社会的、技術的課 題があった。対スペイン戦争は要塞技術を必要としたし、海外航路の開拓の ためには航海術、地図製作技術が不可欠であった。また、まさに低地である ことは治水技術を要求した。ステヴィンの著作はそうした全てに関わってい る。

\section{3-2 ステヴィンの「理想都市」計画案}

1649 年に息子のヘンドリックによって編纂された『民生問題』には、行 政と軍事の問題を扱つた 8 つの論文が含まれている。その論文の第 1 が「都 市構造についてVande 0irdening der Steden」と「住宅とそれに付迶する全 てのものの部分構造について Vande 0irdening der deelen eens heys met' $\mathrm{t}$ gheene daer ancleeft」である。両論文は共に、ステヴィンが出版しよ 
うとしたがついに日の目を見ることのなかった『住宅建築』の一部であった。 この 2 つの論文に記述されるS. ステヴィンの「理想都市計画」は以下のよ うである。図7は、デン・ハーグの王立図書館か浙蔵するものである。

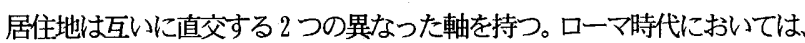
カルド Cardo とデクマヌス Decumanus と呼ばれる 2 つの軸がそれぞれ正確 に南北と東西に走っていて、各軸の端部には門があった。ステヴィン は、 それを意識し、さらに16 世紀半ばにはオランダに紹介されていたイタリア・ ルネッサンスの理想都市計画案を参照している。

しかし、周囲を取り囲む運河と居住地全体を横切る運可は独特である。管 理、コミュニケーション、余倨などのために水を利用する慣習は、低地地方 の典型的な特徴である。中央の運河は、居住地の主要な軸を形成している。 水路は多様な目的に役立つ。それゆえ都市の「生命線」と考光られ、事実、 オランダの都市ではそう考えられてきた。水路、運河は、貯水や循環、排水 といった水の管理に役立つ。そして、水路は精巧な下水道システムの一部と なる。ステヴィンは下水道を道路の舗装の下に計画し、家庭排水を処理して いる。

そして、ステヴィンの関心は、水路の利用できる土地の最大化、街区の宅 地分割の最大化に置かれている。理想都市計画案の全ての街区のほぼ4 分の 1、中央では街区の 4 分の 3 が水に接している。

グリッドへの啫好ははっきりしている26。運可は居住地を 4 つの帯に分割 している。それぞれの帯に 3 列の街区か配置される。街区は 360 フォーテン (voeten フィート) 四方、道路幅 60 フォーテン、運河幅は 180 フォーテン である。道路は、馬車等の車道が 40 フォーテン、両側に 10 フォーテンずつ 歩道をもつ。各街区は背割りする形で $2 \times 10$ の小区画に分割される。各帯が 3 列の街区に分けられているのか江妙である。運河から中央の街区は見るこ とが出来ない。例えば、運河に接して高等学校 Hoogschool と市役所 Stadthuijs か配され、その董側の視界に入らない所には貧しい人々の家 Armhui js がある。各帯の中央は、労働者のための居住区である。街区構成は、 極めて図式的である。 $3 \times 3$ あるいは $3 \times 4$ の大街区となり、一街区分が中間 帯として間に置かれている。

主要な施設を見ると、中央部にあるのが大市場 Grote Marctと取引所Beurse である。ふたつの施設は貿易に関わる。専制体制であるならば、王族や貴族は 居留地の中央に配置されるだろう。だがここでは、王宮 Vorstelick Huijs of hof のための区画が中央上端に位置している。市場を中心とする都市の編成が 強調されているといっていい。

大市場の近くには、中央の2つの帯の中に、小麦 Coornmarct、動物 Beestemarct、木材Houtmarct、石材Steenmarctの市場も配置されている。

取引所のある広場は重要な社会的公的機能を持った建築群一中央教会、市役 所、刑務所、非行少年収容施設に囲まれている。そして、外国人貿易業者のた めの家を表す、M、N、0、街区か隣接している。様々な社会階層か集住すると いう理念をそこに見ることができる。市場原理のみに基づく民主的編成という より、有力な社会集団の参加嘟市行政に不可欠であるという実用主義による。 興味深いのは、オランダか淙教や宗派の相違に比較的寛容だった事である。 中央に位置する主教会の他に、四力所の教会区画力゙用意されている。主教会 はもちろんプロテスタント教会のためのものである。 4 つの教会用地の異な る宗教団体による使用を必ずしもほのめかしているわけではないが、実際の オランダ都市においては、異なる宗派によって使われる場合があり、ユダヤ 教やルター派、英国国教会派、そしてカトリック教会までもある程度許容さ れたのである。

S.ステヴィンの「理想都市」計画案が最も体系的と思われるのは、その拡

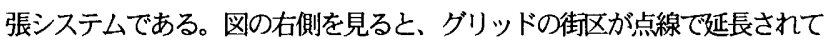
いる。ステヴィンの都市は必要に応じて拡大可能なのである。

一本の運河あるいは川か町に入るところに置かれているのは物々交換や 売買のための埠頭 cade である。逆に川上から送られてきた物は内陸側の埠 頭て処理される。そして、品物は運可や通りによって簡単に街区内部に分配 される。防御上、城壁力設けられ都市は境界つけられる。また、街区の規模、 すなわち建築群と道幅、運河、王宮、公共建築ための土地面積の比例関係は 一定規模に設定されている。しかし、このシステムは理論的に各方向に拡大 可能である。ステヴィンは、運河あるいは川に沿って内陸部へ拡張していく ことを提案するのである。

以上の水路計画、街区計画、施設配置計画、抁張計画がS. ステヴィンの「理 想都市計画」である。その理念が、個々のオランダ植民都市でどのように実 現されようとしたのかが興味深いテーマとなる。

\section{4 バタヴィアとS. ステヴィンの「理想都阨」計画}

S.ステヴィンの「理想都市」計画案をバタヴィアと比較してみよう。

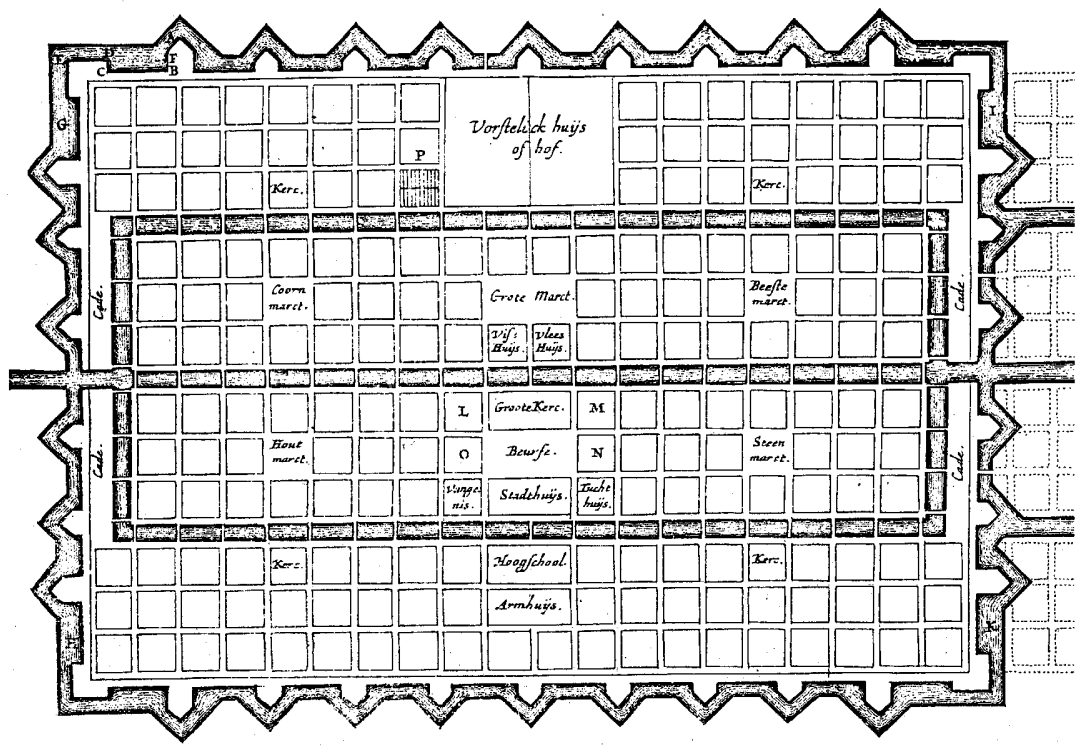

\section{(1) 敖地の選定}

ます敷地の選定について、チリウン川の河ロでジャカト ラ王国の王都が置かれていた場所を選定したJ.P.クーンの 決定は、「遠い土地から流れてくる大きな川の河口に位置 する肥天な土地「海へ出るのと内陸へ向からのと 2 種類 の通行路に恵まれ」「商取引や物流に対して課せられる通 行料や税金による歳入が生み出されるというS. ステヴィ ンの条件にそのまま適っている。チリウン川は、バントゥ ン川とともに内陸のパジャジャラン王国と海域を結ぶ主 要な河川であり、河口はスンダ・カラパの時代から物流の 結節点であり、バタヴィア建設後も後背地の開発にも大き な役割を果たした。

\section{(2)運河システム}

中心となる河川を軸に形成される運河のネットワーク は、オランダの都市の特徴であり、その基本骨格である。 S.ステヴィンの「理想都市」 計画案は、運河のネットワー

図7 S.ステヴィンの[理賏郁市」計画モデル 
クのシステムを図式化したものである。バ夕ヴィアの運河網は、より細かく 複雑に張り巡らしてはいるが (図8)、基本システムとしてはその図式をほぼ そのまま踏襲していると言っていい。中央運河（チリウン川、大川 Groote Rivier）によってオースタースタットとウェスタースタットを分け、それぞれ に運河を周回させている点、市壁外側に沿って運河（影）を周回させている 点、基本システムは同じである。ただ、運河の幅は、S.ステヴィンは $180 \mathrm{ft}$. としているが、バタヴィアの場合、中央運河でも約 $84 \mathrm{ft}$.しかない。よ細か い水循環・管理システムが採用されている。

\section{(3)要塞、市壁、稜堡}

バタヴィア城の建設に、当時の最先端モデルであったS．ステヴィンの稯 堡多角形システムが適用されようとしたことは明らかである (図9)。具体的 に2つの案が送られているのである。バ夕ヴィア以降のオランダ要塞に流行 する 5 角形案性採用されないが、バタヴィア城は、 17 世紀にオランダのみな らずヨーロッパ諸国がアジアに建てた要塞のうち最も大きく様々な要素を 含んだ複合建築である。ただ、S.ステヴィンのモデルには要塞はない。行政 機能を備えた中心としては王宮が市壁内に置かれているだけである。バ夕ヴ ィア城を王宮に見立てるとする亡、河口に置かれているのが大きな違いであ る。市壁か泗角く市街を取り囲み、稜堡が一定の間隔で置かれているのは、 およそS.ステヴィン・モデルに従っていると考えていいだろう。

\section{(4)市場}

S.ステヴィン・モデルは、運可網に次ぐ第2の要素として、6つの市場を、 中央に大市場 Grote Marct と取引所 Beurse、河口側に麦 Coornmarct 市場と木 材 Houtmarc 市場、内陸側に肉 Beestemarct 市場と石材 Steenmarct 市場が中央 運河を挟んで対称に配している。

バ夕ヴィアの場合、必ずしも、以上の配置を意識しているとは思われない (図 10)。唯一、最大の市場フローエンテ・エン・ヘンダー (野菜・家舍) 市場 Groente en Hoender Markt が中央に置かれている点がS.ステヴィン・モデ ルと同じである。1770 年の地図をみると市壁の内外に少なくとも 5 つの市場 がある 27。いずれも運河沿いにあるのか特徴である。フローエンテ・エン・ ヘンダー市場はチリウン川の西岸 ポルトガル教会前にあった。一般の市場 は野天であったが、ここにはフェンスで覆われた四角い建物が建てられてい た。その南の中央 Middelpunt 橋の西岸に花市場、北のマレ一運河を越えたと ころに魚市場Visch Markt があった。この魚市場は 1630 年代に設置され 1846 年に市壁外の現在のパサール・イカンに移された。オースタースタッツの南 の新門 Nieupoort にあるのは木材市場Hout Markt である。唯一市壁外、西南 の角にあるのは竹市場 Bamboese Markt である。ヴァレンタインが米市場、布 市場、陶器市場などとともに、チリウン川上に 2 つ肉市場があったことを 記述しているように、以上の 5 つ以外にも数多くの市場があったことが想定 される。

\section{(5)公共施殿}

S.ステヴィン・モデルの場合、公共施設は中央に集中している。中心に置 かれているのが中央運河を挟んで刘称の位置にある大市場と取引所である。 この配置がS.ステヴィン・モデルの第3の特徴である。主教会 Groote Ker k、 市役所 Stadhuijs、刑務所 Vangenis、集会所 Tuchthuijs、大学（カレッジ） Hoogeschool、救負院Armhuijs と外国人貿易商の住居力取引所を取り囲み、大 市場に隣接して肉小屋 Vleeshuijs、魚小屋 Vishuijs が設置されている。

バタヴィアの場合、公共施設として、1770 年の地図には、市役所、2つの 病院 (ビネン病院 Binnenhospitaal とチャイニーズ病院)、孤児院 Het Wees、刑 務所 Spin Huis が描かれている。また、1625 年に建てられた 2 つの学校 (1 つは女学校 があった28。いずれも中央になく、オースタースタットの南の
街区、ウェスタースタットの南西の街区に集中している。

というより、バタヴィアの中心は市域の中央ではなく、チリウン川沿いの 最も大きいオースタースタットの南の区画に置かれている。そこには市庁舎 Stadhuis が建ち、市庁舎前広場Stadhuis Plein を中心に、オラン夕改革派教会 Hollandsche Kerk など公共的施設か配置されている。また、その周辺にカンパ ニ一病院などが設置されている。ウェスタースタットもそれに対応するよう に、南の区画に病院、孤喟院、刑務所などが建てられている。

中心広場を囲んで公共施設を配する理念ははっきりしている。しかし、そ の位置は異なっている。S.ステヴィン・モデルとの差異は、都市の規模、都 市軸の違いと関係している。

\section{6宗教施設}

S.ステヴィン・モデルの第4の要素となっているのは，左右前後対称の位 置に置かれた 4つの教会敷地である。オランダが植民地において宗教に関し て極めて寛容であったことは特記すべきことである。S.ステヴィン・モデル は、中心に配されるオラン夕改革派教会とは別に 4 つの教会用地を用意する ことにおいてそれを示している。邦祭、オランダ植民都市には、カソリック

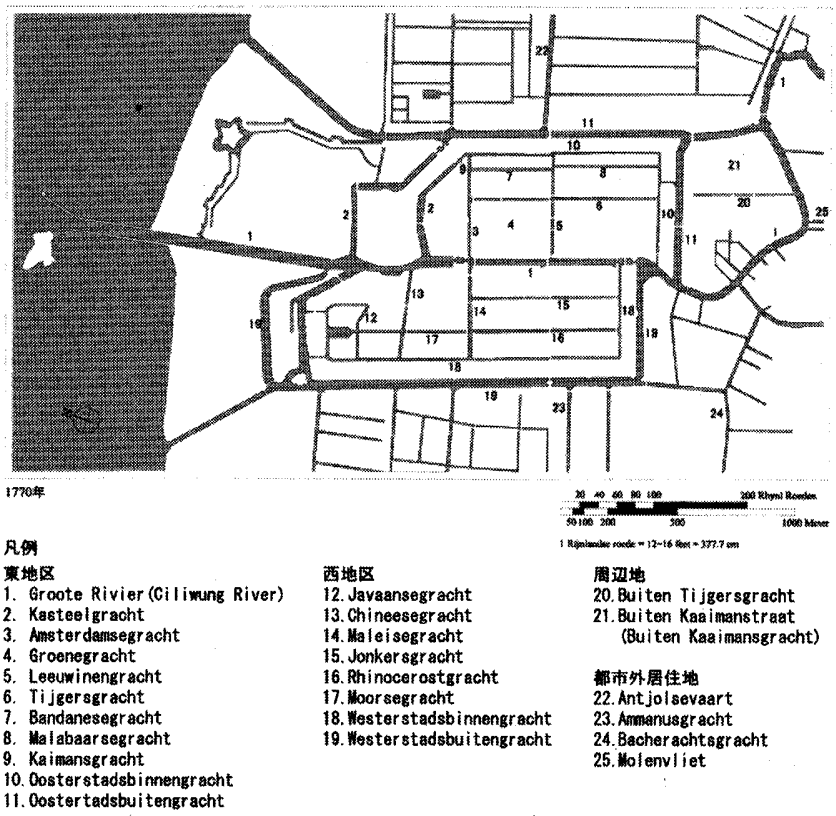

图8 息的網

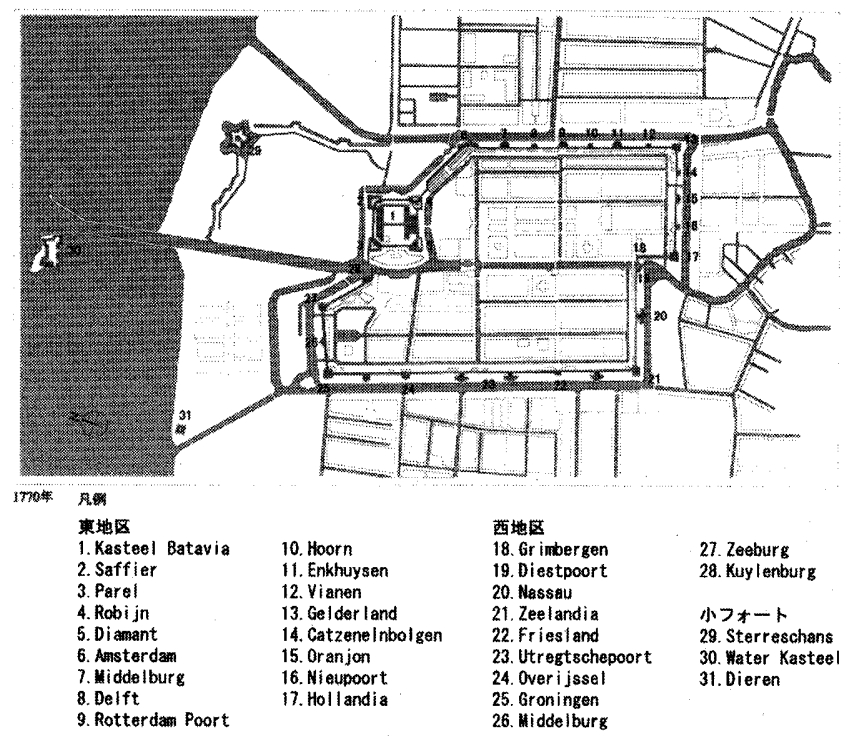

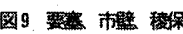


教会、英国国教会、シナゴーグを含めて、宗派の異なる教会が建てられた。 ポルトガル、スペインの場合と大きな違いである。バ夕ヴィアの場合、市壁 内には5つの教会があり、そのうちの3つ、ルーテル Lutheran 教会、ポルト ガル教会 Portugueesche Kerk、オランダ改革派教会 Hollandsche Kerk はチリウ ン川沿いに並んでいた。マレ一教会はビネン病院の南の角にあり、バ夕ヴィ ア城内に兵士用の小教会があった。また、市壁外にポルトガル・ブイテン教 会があった。

それぞれの教会の立地は、S.ステヴィン・モデルとは異なるが、チリウン 川沿いの 3 教会はバタヴィアの中央に位置し、その景観を特徵づけていた。

\section{(7)街路之街区}

第5に、S.ステヴィンは街路と街区について極めて整然としたモデルを示 している。S．ステヴィンのモデルでは、運河は居住地を 4 つの帯に分割し ている。それぞれの帯に3列の街区か配置される。街区は $360 \mathrm{ft}$ 四方、道路 幅 $60 \mathrm{ft}$ 、運河幅は $180 \mathrm{ft}$ である。道路は、馬車等の車道が $40 \mathrm{ft}$ 、雨側に $10 \mathrm{ft}$

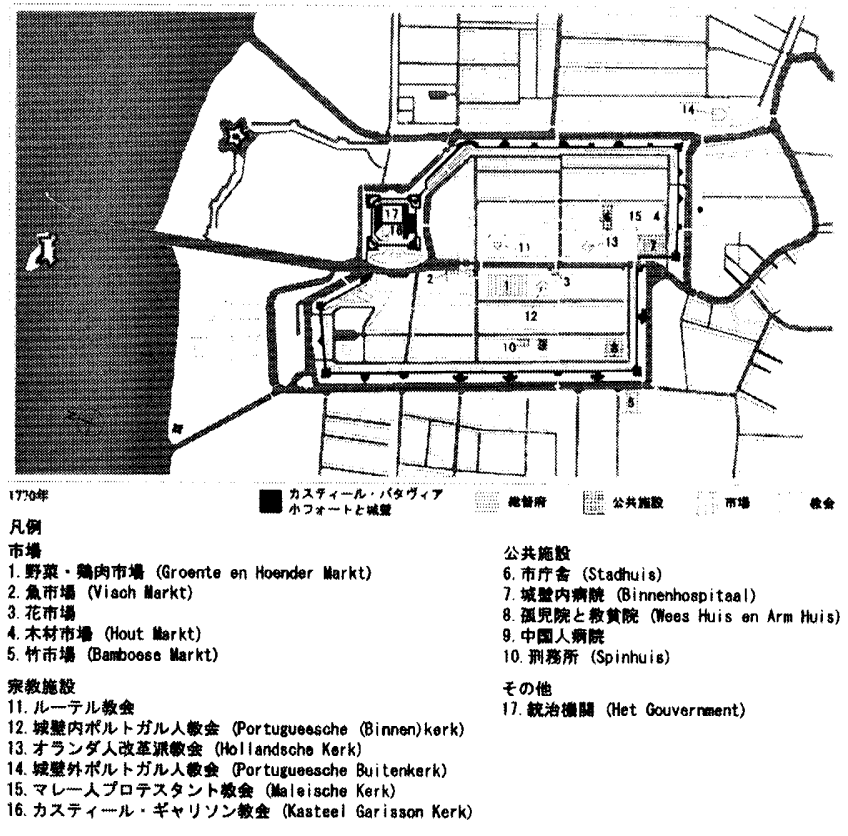

图 10 秎役分

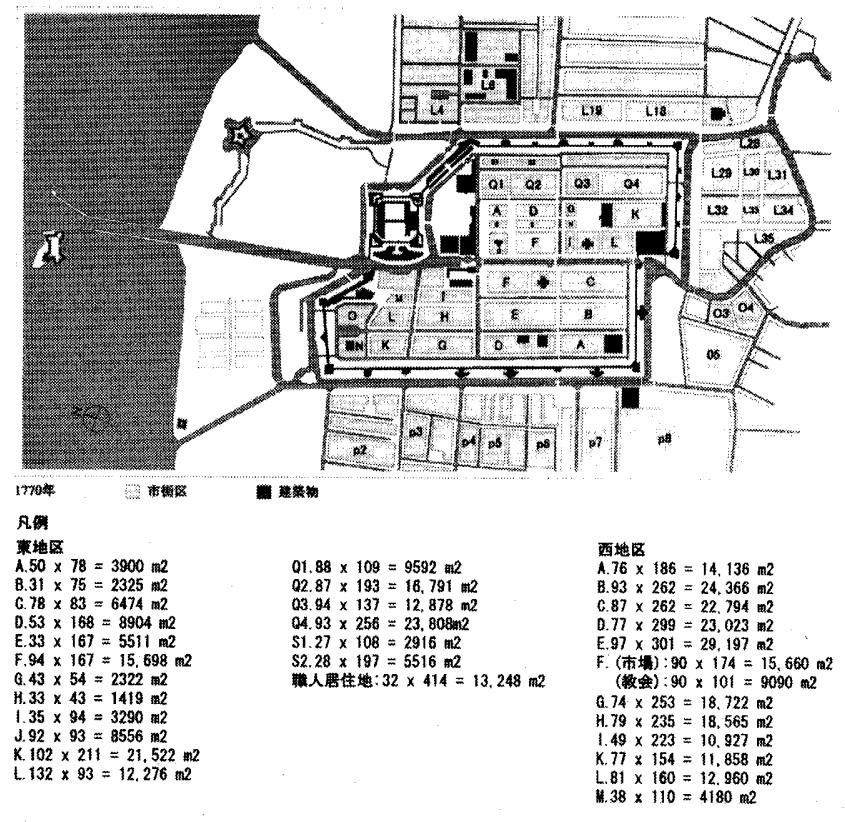

图11 徍规期
ずつ歩道をもつ。各街区は背割りする形で $2 \times 10$ の小区画に分割される。街 区構成は、極めて四式的である。 $3 \times 3$ あるいは $3 \times 4$ の街区が大街区とされ、

一街区分が中間帯として間に置かれている。都市の全体規模は、長軸=60ft (道路幅) $\times 21+360 \mathrm{ft}$ (街区幅) $\times 20=8460 \mathrm{ft}=2578 \mathrm{~m}$ 、短軸 $=180 \mathrm{ft}$ (運 河幅） $\times 3+60$ ft (街路幅) $\times 16+360 \mathrm{ft}$ (街区幅) $\times 12=5820 \mathrm{ft}=1773 \mathrm{~m}$ で ある。

バタヴィアの場合、運河網が、街路そして街区の形態を大きく決定づけて いる (図11)。1627 年のタイガー運河の敷設によって、オースタースタッツ は3つのバンド(帯状地区) に区画されるが、各区画の規模は一様ではない。 また各バンドはいくつかの街区に分けられるが、これも様々である。1635 年 にウェスタースタッツが計画される。オースタースタッツに比べると各街区 の規模はある程度一定している。また、大きい。オースタースタッツの街 規模は 1419 m約 $110 \times 143$ square feet (Block H) $\sim 23,808 \mathrm{~m}^{2}$ (Block Q4)m². ウェスタースタッツは $4180 \mathrm{~m}^{2}($ Block M) 29,197 m² $323 \times 1003$ square feet (BlockE)である。そして、各街区が中庭を囲む形の住居群で構成されるのが 特徴である。街路幅は運河沿いの通りが 100ft、他は 33ft〜80ftである。最大 の街路はアムステルダム運河に隣接する街区（blockA, B and C) の 45m であ る。全体の規模は、およそ、 $1300 \mathrm{~m} \times 920 \mathrm{~m}$ であるから S.ステヴィンの $1 / 4$ 強の大きさということになる。

建設過程からも明らかなように、厳密に幾何学的秩序を導入する構えはな い。というより、そういう余裕は無かったと言えるであろう。チリウン川と 小河川を角提にした建設計哂がなされたのは当然であった。しかし、ウェス タースタットの建設にかかった 1620 年代後半は、より整然とした街区割り が意識されていることは明らかである。ヤックス・スペックスが一定の街区 㓶りを意識していたことは疑いがない。しかし、結果として、街规規模、 宅地の規模にはかなりのばらつきが物じているのは明らかである。

ただ、ウェスタースタットの地㕳をみると、中庭を囲を住区の構成法を明 確にみることができる。街区単位の構成ははっきり急識されていたと考えら れる。

\section{8波止場 Caden}

第6に、S.ステヴィンのモデルには波止場が .力所、㠹への出入口に書 き込まれている。物資の荷揚げを行う場所である。この波止場はバタヴィア では導入されなかったようである。1623 年まで、取引は全てバ夕ヴィア城 内で行われた29。以降は、市内で取引か行われ、外国人は城内に入ることを 禁じられている。取引が行われた市場は、上に見たとおりである。市場が全 て運河沿いに置かれているのは直接物資か洀入搬出されたことを示してい る。波止場のシステムに近いのは南のニーウポールト (新門)に隣接する木 材市場である。上流から搬送されて来た材を入口で荷揚げするのは自然で あるが、.ステヴィン・モデルもそのことを示唆推奨していたと考えられる。

\section{5 まとめ}

以上のように、S.ステヴィンの提唱するほとんどの要素はバタヴィアに見 ることができる。そして、両者の関係は、理念とその実施、図式とその現実 的適用と考えていい。しかし、大きな違いもある。第1の違いは、上述した ように、要塞と王宮の存在・不在である。両者の機能を統治機構ということ で同じと考えると、その位置が異なる。そして、その位置の違いは都市軸の 構成に大きな影響を与えている。それが第2の違いである。

S.ステヴィンのモデルは、中央運河が規定する第 1 の軸と中央に置かれる 王宮一大市場一取引所という行政関連の第2 の軸から明快に構成されてい る。ところがバタヴィアの場合、第1の中央運河の軸とともに主要な軸とな 
っているのはそれと平行するバタヴィア城之市庁舎を結ふ渚市軸である。市 庁舎らはバタヴィア城へ真つ直ぐプリンセス通り Prinsestraat が伸びている。 結果として、市の中心はオースタースタットに偏っている。当初、オースタ ースタットを建設したのだから当然といえば当然である。

ただ、興味深いことは第2軸が意識されていることである。すなわち、東 門 (ロッテルダム門) と西門 (ユトレヒト門)を結ぶ蓮河 (レーウィネン運 河)、街路が主軸に直行しているのである。ただ、この軸梳、S.ステヴィン・ モデルと全く機能を異にし、市の東西への発展のための軸である。フォアス タットの設定に見られるように主軸となる中央運河沿いに、都市を延長する 理念はバ夕ヴィアにもある。しかし、東西に市を拡大するシステムの提案は S. ステヴィン・モデルにはないのである。アムステルダムにしても、実際 の都市化は主軸と直行する方向に起こったのであり、バタヴィアの場合も、 現実の都市発展の方向を考えて、東闆の軸がつくられたと考えられる。 他のオランダ植民都市とS.ステヴィンの「理想都市」計画案の比較につい ては別稿としたい。

註

1 文部省科学研究費助成研究、主查布野修司、1999年一2001年。植民都市研究は (支配 ↔被支配〈 研究である。また夷践的には、植民地期に形成された都市核の再開発が都市言十画上の課題 になり、植民都市遺産を否定するのか、継承するのかが大きなテ一マととりつつある。 2 オランダ東インド会社VOC評議会は、1618 年 4 月、 5 角形の要塞案とS. ステヴィンの 4 解の要塞㧍よひ都市案をバタヴィアのクーンの元に送っている。Raben, Remoo(1996). P11.

${ }^{3}$ Raben, Remoo. 1996.

4 F.de Haan, "Oud Batavia", G. Colff \& Co., Batavia, 1922

5 P.D. Milone, "Queen City of the East: The Metamorphosis of a Colonial Capital", PhD. Dissertation, University of California, Berkeley, 1966.

6 J.L Cobban, "The City on Java, An Essay in Historical Geography", $\mathrm{PhD}$.

Dissertation, University of California, Berkeley, 1970.

7 S.Abeyasekere, "Jakarta. A history", Oxford University Press, 1987.(ed), "From Batavia to Jakarta", Monash University, 1985.'Slaves in Batavia: Insights from a Slave Register'in A.Read(ed),"Slavery, Bondage and Dependency in Southeast Asia", St. Martin's Press.

${ }^{8}$ J.G. Taylor, "The Social World of Batavia - European and Eurasian in Dutch Asia", The University of Wisconsin Press, 1983

9 Edward Ebing and Youetta de Jager, "Batavia- Jakarta 1600-2000 A Binbliography", KITLV Press, Leidenn, 2000.

${ }^{10}$ Brommer, Bea with de Vries, Dirk, "Historische Plattegronden van Nederlandse

Steden deel 4 Batavia", Te Alphine aan den Rijn, 1992

11 Surakarta、聖なる偉業、ともされる。

${ }_{12}$ Heuken, A.SJ, "The Earliest Portuguese Sources for the History of Jakarta:

Including All other Historical Documents from the $5^{\text {th }}$ to the $16^{\text {th }}$ Centuries", Yayasan

Cipta Loka Caraka, Jakarta,2002.. トメ・ピレス以前の資料として举げられるのは プ ラサスティ・トゥグPrasasti Tugu と呼ばれる碑文 (5c)、法顕伝の記述 (414) など7資 料で、琉球王国の漢文資料も含まれている。ポルトガル資料は、ピレス、バルポア、バロ スなど 12 資料、中国文献は 2 点である。

13 De Haan(1922) p. 27. Ijzerman, J.W., “Over de belegering van het Fort

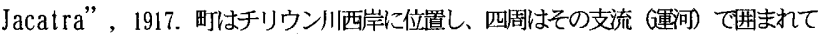
いる。全体は竹垣で囲われていた。クラトンの中には、ダレムという王の住居か㯰かれ、 その前にアルン・アルンがある。貴族たちの住居はその周囲に建ち亚九でいた。アルン・ アルンの西にモスクが建ち、北には市場パサールがある。中国人の䧸地はクラトンの向 か心側東岸にあった。また、東岸にはキヤイ・アリヤKjai Aria と呼ばれる官陧たちの居 住区があった。

14 クーンは、ホールンに生まれ、13歳でローマに赴きフランドル商人のもとで動いてい る。東インドには 1607 年に渡り、

1611 年に一旦帰国している。クーンについては、永積昭（1971）『オランダ東インド会 社』が1韩いている。

15 生田滋「ヤン・ピーテルスソヘン・クーンとバタヴィアの建設、友杉孝編『アジア 都市の諸相比較都市論にむけて一、同文館、1999年。

161624 年に総督De Carpentierが「17 人重役会」に送ったものと考えられている。

${ }_{17}$ Ibid. Raben, Remoo(1996). P11.

18 生田滋 (1999)。Ibid は 8 月 24〜25 日と推定するが、バタヴィアの命名式か行われた のは8月21 日である (Leonald Blusse'(1988))。

19 バ夕ヴィア城に居住した当初の人員は 143 人で、 77 人はドイツ人、フランス人、スコ ットランド人、イギリス人、フレミングイ、ワロン人だったという。Taylor, Jean(1983). P.6.

20. Surjomihardjo, A, “The Growth of Jakarta”, Jakarta, 1977. 布野修司『カンポの世 界』(1991) 揵設過程を図示している。

21 当初の工事監督 fabriekmeesterに誰力゙当たつたが恃不明であるが、1625年には土地
測量士 landmeter フランス・フローリス・ファン・ベケンローデFrans Florisz van Beckenrode が派遣され(1625-34)、初代の建築主事 rooimeester に就任している(1627)。

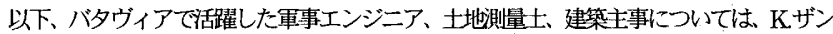
トフリートが明らかにするところである。Zandvliet, K.(1998): "Mapping for Money ${ }^{22}$ Gilles Venant.フェナントはVOC 商人として 1619 年にジャカトラを訪れ、1623 年に 自由市民となって売春宿を経営したとされる。また、船舶を所有して夕イ、日本と銀を主 とする貿易を英国との間で行った。フナントは裁判にかけられ、東インドから退去させ られている。その時競売にかけられたその財産についての記録残つている。1628年に 日本の倭完のバ夕ヴィア攻撃に対する防戦に参加した後、帰国している。

23 Raben, Remoo, 1996. p.15.

24 塚原東至訳、朝倉書店、2000 年。K. van Berkel: In het voetspoor van Stevin、 Geschiedens van de natuurwetenschap in Nederland 1580-1940、Boom Meppel. Amsterdam、 1985

25 Dijksterhuis, EJ,, “The Principal Works of Simon Stevin”, C.V.Swets \& Zeittinger. 1955. 26 「平らな長方形の土地愀の考えでは、長方形の街区、小区画、住宅、宮廷 商店、 公共空間を適切に配置するのに最も適した都市の形で、他の形では合わないか、使うこと ができない。なぜなら、5 角形や多解形の都市では、パルマPalma やコーフォーレン Coevoorden や他の新たに建設された都市や城に見られるように、たとえ それらが中央 部の便利な商店と、士毗まで続く道路、対称的な秩序を持ったあらゆるもので円形に構成 されていても、多くの住宅や街区、小区画は不規則で、一方の端部の幅力池方より広くな ってしまうからである。」

27 市役所前広場に 1620 年代に「新市場」(織物市場) か設置され、1690年代まで存続し たことがわかっている。

${ }^{28}$ Cobban, James. 1971.p.77

29 Cobban, James. 1971.p.76

\section{主要参考文献}

[1] Abeyasekere, S. “Jakarta: A history”, Oxford University Press, 1987

[2] Abeyasekere, S., (ed), "From Batavia to Jakarta", Monash University, 1985

[3]Ali, R.M. and Bodmer, F., "Djakarta through the ages", Government of the Capital

City of Djakarta, 1969

[4]Bagos, A and Wiryomariono, "Seni Bangunan dan Seni Bikota di Indonesia",

Penerbit PT Gramedia Pustaka Utama, Jakarta, 1995

[5]Braam, Dondrecht, Amsterdam: Gerard onder de Linden, 1672

[6] Cobban, James; "The City on Java:An Essay in Historical Geography", California

University, Berkeley, 1971

[7] De Haan, Ijzerman, J.W., "Over de belegering van het Fort Jacatra", 1917

[8]De Haan,F., "Oud Batavia", Gedenkboek uitgegeven ter gelegenheid van het

300-jarig bestaan der stad in 1919, Batavia, 2 vols. G. Colff \& Co., Batavia, 1922

[9]De Vletter, "Batavia/Djakarta/Jakarta - Beeld van een metamorphose", Asia Maior,

Netherlands, 1997

[10]Ebing, Edward and de Jager, Youetta, "Batavia- Jakarta 1600-2000A

Binbliography", KITLV Press, Leidenn, 2000

[11]Ferianto, Bambang Farid, "AStudy on the Spatial Formation of Kampung Luar

Batng, Sunda Kelapa, Jakarta", Master Thesis, Graduate School of Architecture,

Kyoto University, 2003

[12]布野修司、『カンポンの世界 ジャワの庶民住居誌、パルב出版、1991 年

[13]Heuken, Adolf, "Historical Sites of Jakarta", Times Book International, Singapore 1989

[Heuken, Adolf, "Tempat-tempat Bersejarah di Jakarta", Cipta Loka Caraka, Jakarta, 1997

[14]Heuken, Adolf, "The Earliest Portuguese Sources for the History of Jakarta", Cipta Loka Caraka, Jakarta, 2002

[15]Mann, Richard, 'The Old City of Jakarta - Today", Gateway Books, Jakarta, 1998 [16]Milone, P.D., "Urban areas in Indonesia", University California, 1966

[17]Milone, P.D., "Queen City of the East: The Metamorphosis of a Colonial Capital',

PhD. Dissertation, University of Califomia, Berkeley, 1966.

村上直次譈尺、中村孝志校注、『バ夕ピア城日誌 1 3、平凡社、東洋文庫、1975 年

[18]Nas, Peter, "Issues in Urban Development - Case Studies from Indonesia",

Reseanch School CNWS, Leiden University, Netherlands, 1995

[19]Nas, Peter, "Jakarta - Batavia, Socio-cultural Essays", KITLV Press, Leiden, 2000

[20]Nas, Peter J.M.(ed), "The Indonesian City: Studies in Urban Development and

Planning", Foris Publication, KITLV, Leiden, 1986

[21] Raben, Remo, "Round about Batavia and Settlement in the Ommelanden,

1650-1800", CNWS Workshop, Leiden, 1991

[22]Rigg, Jonathan "Indonesian Heritage - The Human Environment", Archipelago

Press, Singapore, 1999

[23]Surjomihardjo, A., "The Growth of Jakarta", Jakarta, 1977

[24] Taylor, J.G. "The Social World of Batavia - European and Eurasian in Dutch

Asia", The University of Wisconsin Press, 1983

[25]Tellander, M. L., Colonial Architecture in Indonesia", University of California

Davis, 1988

[26]Tjahjono, Gunawan, "Indonesian Heritage - Architecture", Archipelago Press,

Singapore, 1999

[27] Valentijn, Franoois, "Beshryving van Groot Djava ofte Java Major", Joannes van

[28]Voskuil, R.P.G.A., "Batavia - Beeld van een stad", Asia Maior, Netherlands, 1997

Yuwono, Martono, "Historic Preservation and Development Plan for the Restoration

Area Jakarta Kota, Jakarta”, Jakarta, 1986

（2004年12月 10 日原稿受理， 2005 年 2 月 18 日採用決定） 